\title{
Keterlibatan Amerika Serikat di Kawasan Golden Crescent: Analisis Geopolitik terhadap Kejahatan Transnasional
}

\author{
Hilda Ariastuti \\ Universitas Airlangga
}

\begin{abstract}
ABSTRAK
Artikel ini menganalisis kejahatan transnasional terorganisir yang terjadi di kawasan Golden Crescent yang merupakan kawasan penghasil opium terbesar di dunia, serta keterlibatan Amerika Serikat di dalamnya. Secara spesifik, penulis membahas basis produksi opium di wilayah Golden Crescent dan mengerucutkannya ke dalam satu negara, yakni Afghanistan. Terdapat dua temuan utama dalam penelitian ini, yaitu wilayah Golden Crescent sebagai produsen dan distributor utama dari perdagangan opium global dan adanya faktor kepentingan bisnis serta politik yang dibawa oleh Amerika Serikat dalam invasinya ke Afghanistan. Salah satunya adalah ketertarikan terhadap perdagangan narkotika yang dinilai memberikan keuntungan dalam jumlah besar. Penelitian ini berkesimpulan bahwa Amerika Serikat memiliki motif keuntungan politik dan ekonomi dalam invasinya ke Afghanistan serta dalam keterlibatannya di Golden Crescent.
\end{abstract}

Kata-kata Kunci: Kejahatan transnasional terorganisir, perdagangan narkotika, Golden Crescent, Afghanistan, Amerika Serikat

This article analyzes the phenomenon of transnational organized crime in the Golden Crescent, one of the biggest producers of opium globally, and the United States' involvement in the region. The author discusses the production base for opium in the Golden Crescent by focusing on one country, namely Afghanistan. There are two main findings in this study, namely the Golden Crescent region as a significant producer and distributor of the global opium trade; and the business and political interests that the United States brought in its invasion of Afghanistan. One of them is his interest in drug trafficking, which is considered to be highly profitable. This research concludes that the United States has political and economic advantage motives in its invasion of Afghanistan and its involvement in the Golden Crescent.

Keywords: Transnational organized crimes, drugs trafficking, Golden Crescent, Afghanistan, United States 
Era globalisasi membawa dampak yang signifikan terhadap fenomena-fenomena lintas-batas, utamanya dipengaruhi oleh semakin derasnya arus mobilitas manusia dan informasi yang disebabkan perkembangan teknologi. Salah satunya adalah kemunculan darikejahatan terorganisir transnasional (transnational organized crimes). Kejahatan terorganisir transnasional merupakan suatu kegiatan terorganisir yang memiliki tujuan utama untuk mendapatkan keuntungan melalui cara-cara ilegal, salah satunya dengan menjual komoditas dagang apapun yang dapat memberikan keuntungan maksimal dengan risiko yang seminimal mungkin (McFarlane 2001). Kegiatan kejahatan transnasional ini antara lain meliputi pencucian uang, terorisme, perdagangan narkotika, penyelundupan hewan, penjualan senjata, pembajakan, perdagangan manusia seperti penjualan organ tubuh manusia dan prostitusi, serta berbagai kejahatan lainnya yang melintasi batas negara. (McFarlane 2001).

Kejahatan transnasional adalah bentuk kejahatan yang menimbulkan ancaman serta tantangan serius bagi keamanan dan stabilitas global mengingat sifatnya yang melewati lintas batas negara sehingga dalam hal ini kejahatan transnasional juga digambarkan sebagai kejahatan yang melibatkan adanya perpindahan kegiatan kriminal dari suatu negara ke negara lain. Selain itu, kejahatan transnasional juga termasuk ke dalam kejahatan yang terjadi di satu negara, tetapi konsekuensinya secara signifikan mempengaruhi negara lain disekitarnya. Menurut May (2017), uang menjadi motivasi utama dalam kejahatan transnasional. Aktivitas ilegal menjadi lahan bisnis utama yang dapat menghasilkan keuntungan besar dengan risiko atau biaya yang rendah. Kejahatan transnasional dalam hal ini memiliki dampak signifikan terhadap individu, komunitas atau masyarakat, serta stabilitas ekonomi, sosial, politik, dan lingkungan dalam suatu negara. Bahkan May (2017) menyatakan bahwa "dirty money begets dirty money", yang berarti pendapatan yang dihasilkan dari kejahatan transnasional tidak hanya mengisi kantong para pelakunya yakni organized crime groups (OCGs), tetapi juga membiayai kegiatan kriminal dan kekerasan lainnya.

Kejahatan transnasional lebih banyak berkembang di negara-negara yang mana lembaga penegak hukumnya dinilai lemah dan warga negara memiliki akses kehidupan ekonomi yang terbatas. Salah satu contohnya adalah munculnya fenomena petani lokal yang mulai beralih ke budidaya narkotika (drug cultivation), sebab budidaya narkotika dianggap lebih menguntungkan dibanding komoditas 
pertanian pada umumnya, seperti gandum atau padi. Jenis tanaman narkotika yang dapat dikultivasi atau dibudidayakan oleh para petani antara lain adalah kokain, opium, dan ganja atau marijuana. Selain itu, bentuk kejahatan transnasional juga dapat dilihat dalam kasus orang-orang yang mencoba mencari pekerjaan atau kehidupan yang lebih baik di luar negaranya namun justru masuk ke dalam lingkaran perbudakan, prostitusi, atau perdagangan organ tubuh ilegal.

Muller (1978 dalam Boister 2003) mendefinisikan kejahatan transnasional sebagai istilah yang lebih mengarah pada aspek kriminologis daripada yuridis, dan istilah ini awalnya diciptakan oleh UN Crime Prevention and Criminal Justice untuk mengidentifikasi fenomena atau tindakan kriminal yang telah melampaui perbatasan internasional,melampauihukumyangberlakudibeberapanegara,dan efeknya berdampak pada negara lain. Istilah kejahatan transnasional lebih mengarah pada deskripsi fungsional daripada normatif, sebab pada tahun 1974 istilah ini digunakan untuk memandu diskusi di salah satu konferensi kriminal yang diselenggarakan Perserikatan Bangsa-Bangsa (PBB). Berdasarkan Artikel 3 Konvensi Kejahatan Terorganisir Transnasional (2000), pertimbangan dari suatu tindakan untuk dapat dikatakan sebagai kejahatan transnasional adalah bila: (1) kejahatan dilakukan di lebih dari satu negara; (2) dilakukan di satu negara tetapi bagian substansial dari persiapan, perencanaan, arahan maupun kontrolnya dilakukan di negara lain; (3) dilakukan di satu negara tetapi melibatkan kelompok kriminal terorganisir yang terlibat dalam kegiatan kriminal di lebih dari satu negara; (4) dilakukan di satu negara tetapi memiliki efek substansial di negara lain.

Tulisan ini bertujuan untuk mengeksplorasi fenomena perdagangan narkotika di wilayah narkotika, dengan fokus utama pada keterlibatan Amerika Serikat di kawasan ini. Tulisan ini bertujuan untuk menjadi sebuah tulisan konseptual yang menjawab pertanyaan terkait intensi Amerika Serikat di kawasan golden crescent. Dengan melakukan analisis geopolitik terhadap potensi keuntungan Amerika Serikat di kawasan ini, penulis akan memaparkan kerangka pemikiran terkait keterlibatan Amerika Serikat di kawasan ini, utamanya dimulai dengan penetrasi pengaruhnya di Afghanistan, sebagai upaya dalam mencapai keuntungan dari perdagangan narkotika sebagai kejahatan transnasional. 


\section{Perdagangan Narkotika di Kawasan Golden Crescent: Sebuah Eksplorasi}

Perdagangan narkotika merupakan salah satu aktivitas utama yang termasuk dalam tipologi kejahatan terorganisir transnasional, dan masih menjadi pembahasan yang signifikan serta krusial dewasa ini. Rémi Boivin (2013) menyatakan bahwa perdagangan narkotika melibatkan adanya serangkaian pertukaran atau transaksi jual-beli antar-pelaku, baik individu atau kelompok yang beroperasi di berbagai negara. Naylor (2003 dalam Boivin 2013) mengatakan bahwa perdagangan narkotika terdiri dari adanya pertukaran multilateral barang-barang yang secara inheren ilegal antara produsen, distributor dan konsumen dalam konteks seperti pasar. Pemahaman Naylor dalam hal ini, sangat relevan, sebab perdagangan narkotika melibatkan pergerakan komoditas ilegal dari sumber atau produsen ke penggunanya atau konsumen, rantai antara keduanya dihubungkan oleh sejumlah perantara tertentudalam konteks ini perantara dapat dikatakan sebagai distributorsehingga hal ini dianggap sebagai elemen "ekonomi", sebab berpusat pada perdagangan komoditas meskipun ilegal. Menurut Jill Sherman (2010), terdapat persamaan argumen bahwa perdagangan narkotika melibatkan adanya pertukaran atau transaksi dari petani ke produsen, selanjutnya ke penyelundup, kemudian ke pengedar atau street dealers hingga akhirnya sampai ke tangan konsumen atau pengguna. Sherman (2010) juga menambahkan bahwa perdagangan narkotika secara terselubung telah mengakar kuat dalam perekonomian global dan industri ilegal bernilai miliaran dolar, dan industri ini dilindungi serta diawasi oleh sekelompok elit yang dikenal sebagai mafia atau kartel narkotika dan jaringannya yang luas menyebar di seluruh dunia (Sherman 2010). Kelompok mafia atau kartel narkotika ini yang kemudian meraup banyak keuntungan dari perdagangan narkotika.

Definisi perdagangan narkotika menurut Sherman (2010) adalah transaksi yang mengacu pada proses ilegal di mana narkotika atau obat-obatan terlarang diproduksi, diangkut atau dibawa, lalu dijual. Sebagian besar jenis tumbuhan narkotika ditanam di negara berkembang, kemudian tumbuhan tersebut diproduksi seperti tanaman opium menjadi heroin dan morfin, atau tumbuhan koka menjadi kokain. Lantas, setelah proses produksi dan menjadi obatobatan kemudian diangkut dan diperjual-belikan di negara-negara pasar dimana narkotika terjual keras. Salah satunya Amerika Serikat dan negara-negara Eropa, di mana jumlah pemakai atau 
pengguna narkotika cukup tinggi. Perdagangan narkotika tidak dilakukan secara terang-terangan karena statusnya yang masih ilegal di banyak negara, namun obat-obatan ini dapat diperjualbelikan di pasar gelap (black market). Terlepas dari statusnya yang masih ilegal, perdagangan narkotika tetap menjadi industri besar yang menghasilkan keuntungan besar dengan risiko rendah dan terus berekspansi menyebar ke seluruh dunia (Sherman 2010). Selanjutnya, Naylor (2003 dalam Boivin 2013) berargumen bahwa pertukaran atau transaksi itu terjadi dengan melibatkan konteks maupun aspek sosial-politik sehingga transaksi narkotika sendiri adalah hal nomor dua, adanya pengaruh dari aspek sosial dan politik membuat perdagangan narkotika menjadi lebih kompleks karena tidak hanya melibatkan produsen, distributor, dan konsumen namun juga melibatkan pihak lain seperti pemerintah sebagai batas yuridiksi. Bahkan di sebagian negara, pemerintah melegalkan penggunaan narkotika dalam batasan tertentu, salah satunya seperti di Belanda, di mana pemerintah Belanda merancang kebijakan penggunaan narkotika dengan mentoleransi pemakaian ganja di bawah syarat dan ketentuan yang ketat. Selain dari aspek sosial dan politik, perdagangan narkotika juga bisa dilihat melalui pendekatan geopolitik (Boivin 2013).

Lantas, dengan menggunakan pendekatan geopolitik, dapat ditentukan negara manakah yang memperoleh keuntungan dan manfaat dari adanya perdagangan narkotika. Hal ini merujuk pada pandangan geopolitik yang menekankan adanya pendekatan kritis terhadap berjalannya praktik analisis, prasyarat, penggunaan kekuatan politik sebagai suatu representasi wilayah atau negara tertentu. Apabila melihat dari pendekatan geopolitik, dapat dijelaskan bahwa negara yang memperoleh keuntungan dan manfaat dari adanya perdagangan narkotika adalah Afghanistan, disebabkan posisi geografisnya yang dinilai sangat menguntungkan sebagai titik perdagangan narkotika. Selain itu, Afghanistan juga terletak di rute perdagangan darat dan perlintasan Eurasia, serta berada di Asia Selatan bagian barat laut, dekat dengan Asia Tengah dan Barat yang kaya akan energi. Wilayah teritorial Afghanistan juga termasuk ke dalam Golden Crescent. Hal ini kemudian membuat Afghanistan dikenal sebagai pusat produksi dan distribusi opium global. Opium menjadi komoditas utama perdagangan dan industri Afghanistan, dengan hampir 90\% opium dan heroin global berasal dari negeri ini (Chouvy 2010 dalam Boivin 2013). 
Selain karena posisinya yang strategis, kondisi politik dalam negeri Afghanistan yang tidak stabil mempengaruhi perkembangan perdagangan narkotika itu sendiri. Berkuasanya para warlords, ditambah dengan pemerintahan dan birokrasi yang lemah serta korup, membuat pihak-pihak tersebut dinilai telah meraup banyak keuntungan dari perdagangan narkotika. Hasil dari perdagangan komoditas opium ini kembali digunakan untuk membiayai perang dan memperkuat pasukan militer setiap faksi yang turut serta dalam perang sipil di Afghanistan. Hal ini dibuktikan dengan peningkatan kehadiran militer di setiap ladang opium milik para petani, salah satunya adalah kehadiran militer Amerika Serikat yang turut andil dalam kegiatan perdagangan narkotika di Afghanistan. Penulis akan secara spesifik menjelaskan mengenai keterlibatan Amerika Serikat dalam lingkaran perdagangan narkotika pada bagian selanjutnya tulisan ini.

Sebelumnya, penulis akan memaparkan mengenai apa yang dimaksud dengan Golden Crescent. Bulan Sabit Emas atau Golden Crescent merupakan istilah yang digunakan untuk mengidentifikasi suatu wilayah penghasil opium terbesar di dunia (Arnold 2013). Wilayah Golden Crescent meliputi Iran, Afghanistan, dan Pakistan yang terletak di Asia Selatan. Wilayah ini dikategorikan sebagai situs global utama dan sumber produksi serta distribusi opium. Dalam kurun waktu beberapa dekade terakhir, perang, konflik, terorisme, dan lanskap politik kawasan ini mengalami transformasi atau pergeseran, mengakibatkan semakin aktifnya perdagangan heroin di kawasan Golden Crescent ini. Konflik sipil dan intervensi asing yang berlarut-larut hingga berkepanjangan telah memperburuk kondisi serta keadaan sosial-ekonomi bahkan instabilitas politik domestik negara-negara yang berada di wilayah Golden Crescent. Adanya perselisihan politik di dalam negeri yang sudah mengerikan dinilai telah memberikan kontribusi terhadap perkembangan dan peningkatan perdagangan obat-obatan terlarang dan berpengaruh terhadap kondisi sosial, yakni salah satunya menimbulkan kecanduan kepada penduduk sekitar serta penyebaran penularan penyakit HIV (Farooq et al. 2017).

Wilayah Golden Crescent, menurut Farooq et al. (2017), dianggap sebagai pusat global untuk heroin dan produksi serta perdagangan opium terkait. Selain itu, dijelaskan juga bahwa tinjauan dalam bahan bacaan ini juga mengeksplorasi bagaimana kekuatankekuatan seperti itu mungkin telah mempengaruhi pertumbuhan dan perluasan perdagangan heroin di kawasan tersebut sehingga 
berimplikasi pada epidemi penggunaan narkotika dalam jenis suntikan. Lantas, hal ini berpengaruh terhadap peningkatan serta penyebaran human immunodeficiency virus (HIV) yang ditularkan melalui darah. Menurut Farooq et al. (2017), terdapat tiga rute dalam perdagangan heroin yang telah terdefinisi dengan baik dan tiga rute ini berasal dari wilayah Golden Crescent yakni: (1) Rute Balkan, beroperasi melalui Iran dan Turki, menyebabkan perdagangan narkotika di rute ini bisa mencapai Eropa; (2) Rute Utara, yang mana rute ini memasok heroin ke Rusia dan Asia Tengah; (3) Rute Laut Selatan yang memperdagangkan heroin dari Iran dan Pakistan ke seluruh dunia. Dalam Rute Selatan ini, perlu digarisbawahi bahwa Afghanistan merupakan negara landlocked, sehingga komoditas dari penjualan narkotikanya harus melewati Pakistan terlebih dahulu. Berdasarkan ketiga rute dari wilayah penyebaran narkotika yang berasal dari Golden Crescent dapat dilihat dalam peta dibawah ini.

\section{Peta 1. Rute-Rute Perdagangan Narkotika di Kawasan Golden Crescent}

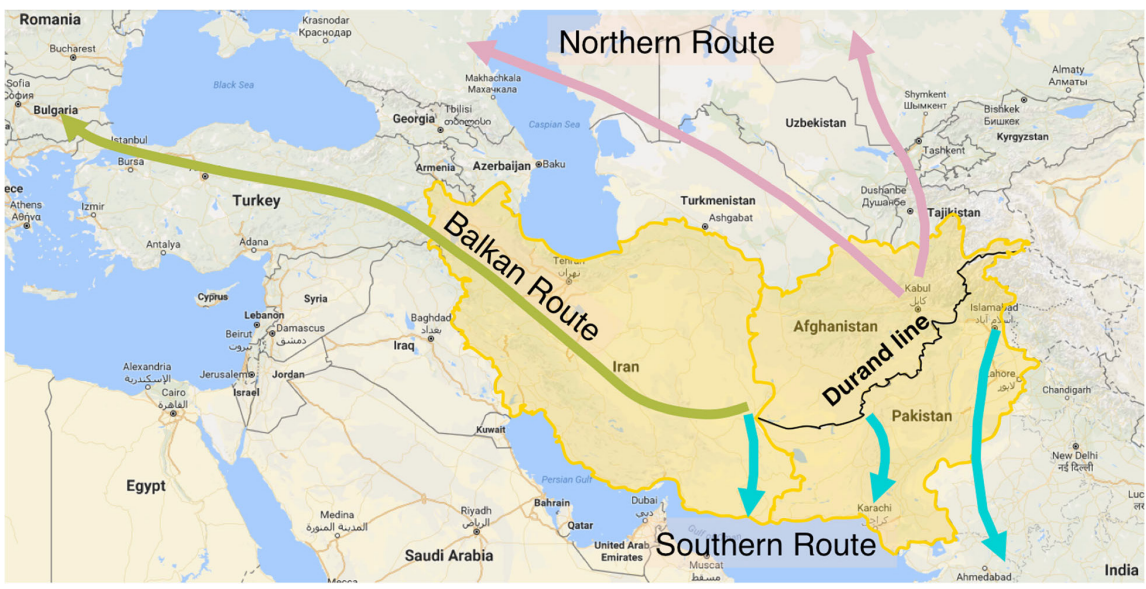

Sumber: Farooq et al. 2017

\section{Keterlibatan Amerika Serikat dalam Perdagangan Narkotika di Afghanistan}

Selanjutnya, penulis akan berfokus terhadap isu seputar perdagangan heroin dan opium di Afghanistan serta implikasinya kepada kehidupan dalam Afghanistan hingga hari ini. Selain itu, penulis juga akan menambahkan sedikit insight mengenai 
keterlibatan politik heroin Amerika Serikat dalam perdagangan narkotika di Afghanistan. Pada tahun 1979, saat Uni Soviet menduduki Afghanistan, negara tersebut jatuh ke dalam perang selama sembilan tahun lamanya. Terdapat banyak gerakan perlawanan dari kaum agamis atau mujahidin yang lantas menjadi cikal bakal dari kelompok teroris Taliban saat ini. Taliban kemudian berhasil menguasai kembali Afghanistan setelah memukul mundur pasukan Uni Soviet. Pada tahun 2001, Afghanistan kembali berhasil di invasi oleh pendudukan asing, namun pada kesempatan ini, aktor utamanya adalah Amerika Serikat. Perang selama satu dekade dengan Uni Soviet telah mengakibatkan kehancuran sektor pertanian Afghanistan. Hal ini diperparah dengan kehadiran Amerika Serikat pasca-kepergian Uni Soviet. Hal ini juga semakin diperburuk dengan hadirnya para warlords yang menetapkan pajak tinggi terhadap rakyat Afghanistan, sehingga pajak yang harus dibayarkan kepada para warlords ini membuat banyak petani tidak punya banyak pilihan selain menanam opium - tanaman yang hanya membutuhkan sedikit air namun menghasilkan keuntungan tinggi (Farooq et al. 2017). Hal ini membuat opium menjadi komoditas utama dari industri agrikultur Afghanistan.

Selanjutnya, keuntungan yang diperoleh dari penjualan opium digunakan untuk mendanai berbagai aktivitas militer, seperti perlawanan Afghanistan terhadap pendudukan Uni Soviet. Produksi opium naik terus sepanjang tahun 1980-an dan 1990-an, hingga pada tahun 2000 produksi opium turun drastis karena adanya fatwa yang dikeluarkan oleh pemimpin Taliban yakni Mullah Omar yang melarang penanaman opium (Farooq et al. 2017). Namun, pascahengkangnya Uni Soviet, produksi opium kembali dikembangkan dan dilanjutkan setelah jatuhnya Taliban pada tahun 2001, dan pada saat invasi Amerika Serikat ke Afghanistan. Perdagangan opium, meskipun tidak dapat diandalkan, telah menjadi usaha yang relatif menguntungkan bagi petani Afghanistan. Hal ini terbukti dalam jangka tahun 2002 hingga 2008 ketika petani opium menghasilkan sekitar 6,4 miliar Dolar Amerika Serikat, dan pengedar narkotika di Afghanistan diperkirakan menghasilkan sekitar 18 miliar Dolar Amerika Serikat (Farooq et al. 2017). Sebagian besar keuntungan jatuh ke tangan warlords dan kelompok teroris, yang mana hasil keuntungan tersebut kemudian digunakan untuk mendanai perang dan kegiatan terorisme. Ketika perdagangan opium mendanai terorisme di Afghanistan, perdagangan opium juga melemahkan integritas dari lembaga-lembaga sipil, lebih jauh lembaga maupun institusi pemerintahan juga tidak dapat dipungkiri turut 
memfasilitasi perdagangan opium ilegal (Farooq et al. 2017). Dapat dilihat dari grafik dibawah ini mengenai peningkatan penanaman opium pasca-kejatuhan Taliban.

Grafik 1. Produksi Opium Afganistan, 1980-2012

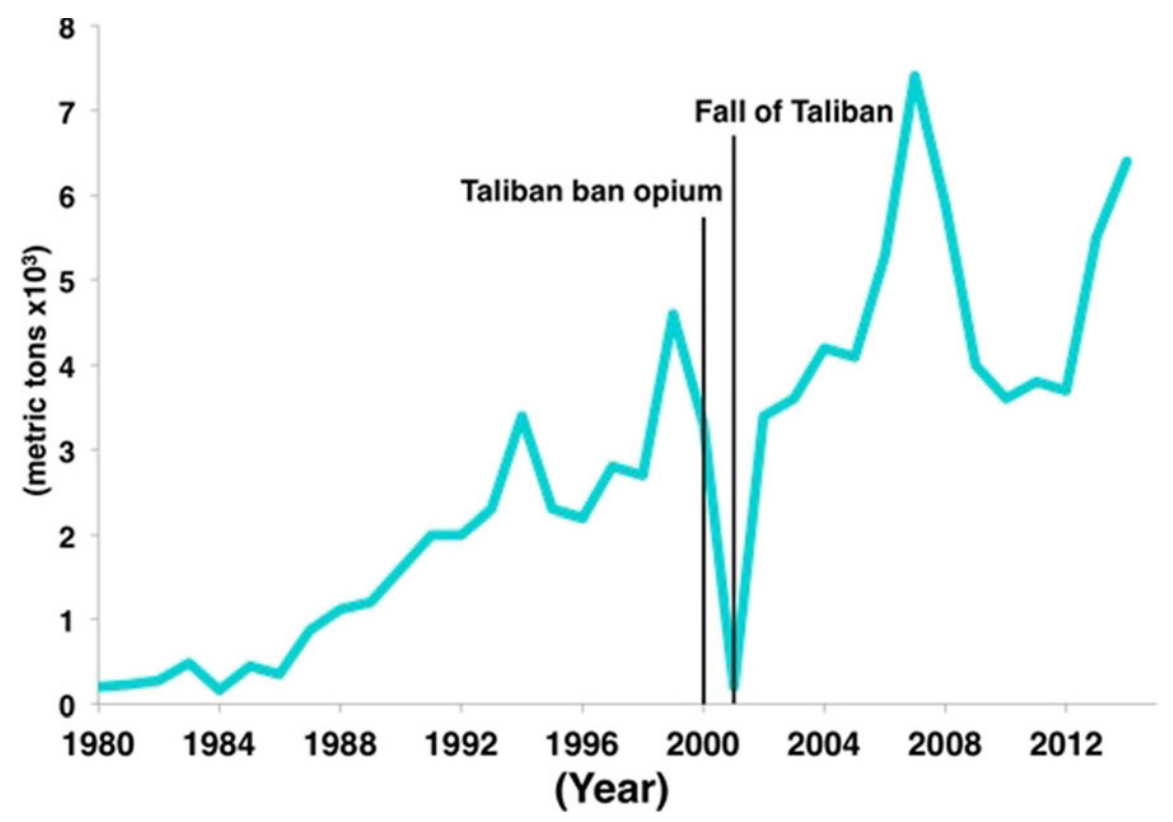

Sumber: Farooq et al. 2017

Lantas, mengemukalah diskursus terkait politik heroin Amerika Serikat di Afghanistan. Mengutip dari pernyataan Michel Chossudovsky (2007), militer Amerika Serikat di Afghanistan memiliki tugas untuk mendukung perdagangan narkotika di Afghanistan guna memasok pasar heroin di Amerika Serikat sendiri, dan bahkan seluruh dunia. Kehadiran militer Amerika Serikat dinilai telah berfungsi untuk memulihkan alih-alih memberantas perdagangan narkotika. Produksi opium telah meningkat tiga puluh tiga kali lipat dari 185 ton pada tahun 2001 pasca-invasi Amerika Serikat di Afghanistan, sedangkan saat di bawah Taliban menjadi 6100 ton pada tahun 2006 (Chossudovsky 2007). Dukungan Amerika Serikat terhadap politik opium secara langsung berkaitan dengan lonjakan konsumsi heroin dan kecanduan di dalam negeri Amerika Serikat yang telah diamati dalam beberapa tahun terakhir. Perdagangan narkotika di wilayah Golden Crescent-terutama Afghanistan-telah diluncurkan oleh Badan Intelejen Pusat (CIA) Amerika Serikat pada awal tahun 1980-an, dan terus dilindungi oleh 
intelijen Amerika Serikat, sehubungan dengan pendudukan pasukan Organisasi Traktat Atlantik Utara (NATO) dan militer Inggris di Afghanistan.

Area budidaya opium terus meningkat sebanyak 21 kali lipat sejak invasi Amerika Serikat tahun 2001. Hal yang tidak pernah diakui pada publik adalah bahwa pemerintahan Taliban berperan sangat penting pada tahun 2000 hingga 2001 terutama dalam mengimplementasikan program pemberantasan narkotika yang sukses, dengan dukungan dan kolaborasi PBB. Diimplementasikan pada tahun 2000 hingga 2001, program pemberantasan narkotika dari Taliban menyebabkan penurunan sekitar 94 persen dalam budidaya opium (Chossudovsky 2007). Pada tahun 2001, menurut catatan PBB, produksi opium turun menjadi 185 ton. Segera setelah invasi oleh Amerika Serikat pada bulan oktober tahun 2001, produksi meningkat secara dramatis, dan pertanian opium kembali mendapatkan tingkat pencapaian yang melampaui sejarahnya. Menurut PBB (dalam Chossudovsky 2007), Afghanistan memasok sekitar 92 persen dari pasokan opium dunia, yang digunakan untuk membuat heroin dalam skala global. PBB (dalam Chossudovsky 2007) memperkirakan bahwa di tahun 2006, kontribusi perdagangan narkotika terhadap ekonomi Afghanistan berada di angka 2,7 miliar Dolar Amerika Serikat. Apa yang tidak disebutkan adalah fakta bahwa lebih dari 95 persen pendapatan yang dihasilkan oleh barang selundupan yang menggiurkan ini diperoleh dari sindikat bisnis, kejahatan terorganisir, serta lembaga keuangan dan perbankan. Hal ini dinilai hanya memberikan persentase yang sangat kecil bagi perekonomian petani opium di dalam negara produsen opium, yakni Afghanistan. Faktanya, Heroin Afghanistan dijual di pasar narkotika internasional dengan harga 100 kali lipat dari harga yang diperoleh petani untuk opium mereka yang langsung dari hasil ladang (Chossudovsky 2007).

Dalam pandangan Amerika Serikat, narkotika adalah barang terpenting kedua setelah Minyak dan Perdagangan Senjata. Perkiraan sebelumnya konsisten dengan penilaian PBB mengenai ukuran dan besarnya perdagangan dari narkotika global. Perdagangan opium Afghanistan merupakan bagian besar dari pergantian tahunan perdagangan narkotika di seluruh dunia, yang diperkirakan oleh PBB adalah mencapai sekitar 400-500 miliar Dolar Amerika Serikat. Berdasarkan catatan pada tahun 2003, perdagangan narkotika merupakan komoditas global terbesar ketiga dalam hal mendapatkan uang setelah perdagangan minyak dan penjualan senjata. 
Dalam hal ini, Afghanistan bersama dengan Kolombia membentuk ekonomi nasional yang berbasis pada perdagangan hasil narkotika terbesar di dunia. Hal ini memberikan dampak positif terhadap perkembangan kejahatan transnasional dan menjadikan ekonomi yang berkembang berdasarkan ekonomi kriminal. Sistem politik domestik dalam negara-negara ini cenderung sangat termiliterisasi yang mana kekuatan militer juga turut serta melindungi perdagangan narkotika. Selain para warlords dan pemangku militer telah didokumentasikan secara luas, sehingga CIA yang merupakan badan intelijen dari Amerika Serikat memainkan peran sentral dalam pengembangan segitiga perdagangan narkotika Amerika Latin dan Asia. Sebagian besar pencucian uang global seperti yang diperkirakan oleh Dana Moneter Internasional (IMF) terkait dengan perdagangan narkotika, banyak yang memiliki keterkaitan langsung, di antaranya berasal dari segitiga opium di wilayah Golden Crescent (Chossudovsky 2005).

Ekonomi narkotika Afghanistan adalah proyek CIA yang dirancang dengan hati-hati, dan didukung oleh kebijakan luar negeri AS (Chossudovsky 2005). Seperti terungkap dalam skandal Iran-Contra dan Bank Dagang \& Kredit Internasional (BCCI), operasi rahasia CIA dalam mendukung Mujahidin Afghanistan telah didanai oleh pencucian uang hasil perdagangan narkotika (Chossudovsky 2005). Uang kotor yang telah didaur ulang-melalui sejumlah lembaga perbankan di Timur Tengah serta melalui perusahaan anonim rekanan CIA-membuat hasil perdagangan narkotika ini menjadi "uang rahasia" yang digunakan untuk membiayai berbagai kelompok pemberontak di Afghanistan selama perang Soviet-Afghanistan. Dalam penelitian karya Alfred McCoy (dalam Chossudovsky 2005), dikonfirmasi bahwa pada tahun 1995, mantan direktur CIA yang beroperasi Afghanistan-Charles Cogan-mengakui bahwa CIA memang telah mengorbankan perang narkotika untuk memenangkan Perang Dingin. Ia mengakui bahwa misi utama dari Amerika Serikat adalah melakukan sebanyak mungkin kerusakan pada Uni Soviet.

Peran CIA yang tidak banyak didokumentasikan tidak pernah disebutkan dalam publikasi resmi dari Kantor Narkotika dan Kejahatan PBB (UNODC) yang hanya berfokus pada faktor sosial dan politik internal di Afghanistan saja. Sehingga, tidak perlu diperjelas bahwa akar sejarah perdagangan opium telah sangat terdistorsi. Ada kepentingan bisnis dan finansial yang kuat di balik perdagangan narkotika. Dari sudut pandang ini, kontrol geopolitik dan militer atas rute narkotika sama strategisnya dengan jaringan 
pipa minyak dan gas. Namun, yang membedakan narkotika dari perdagangan komoditas legal adalah bahwa narkotika merupakan sumber utama pembentukan kekayaan tidak hanya untuk kejahatan terorganisir, tetapi juga untuk aparat intelijen AS, yang mana perdangangan komoditas narkotika semakin menjadi aktor kuat di bidang keuangan dan perbankan. CIA yang telah melindungi perdagangan obat-obatan terlarang, telah mengembangkan bisnis yang kompleks dan hubungan rahasia dengan sindikat kriminal utama yang terlibat juga dalam perdagangan narkotika.Dengan kata lain, agen intelijen seperti CIA dan sindikat bisnis yang kuat seperti kartel narkotika bersekutu dengan kejahatan terorganisir, bersaing untuk kontrol strategis atas rute heroin. Pendapatan narkotika bernilai miliaran dolar disimpan dalam sistem perbankan Barat. Sebagian besar bank internasional besar bersama-sama dengan afiliasinya di perbankan lepas pantai telah mencuci sejumlah besar dolar narco (Chossudovsky, 2005).

Perdagangan ini hanya bisa makmur jika aktor utama yang terlibat dalam perdagangan narkotika memiliki "teman politik di tempat yang tinggi" serta upaya hukum dan ilegal yang semakin terjalin, garis pemisah antara "pengusaha" dan "penjahat" menjadi semakin blur dan kabur. Pada gilirannya, hubungan di antara para penjahat, politisi dan anggota badan intelijen telah menodai struktur negara dan peran lembaga-lembaganya yang seharusnya berfungsi sesuai pelayanan publik. Kebijakan luar negeri Amerika Serikat dengan mendukung cara kerja ekonomi kriminal yang berkembang di mana demarkasi antara modal terorganisir dan kejahatan terorganisir semakin kabur. Bisnis heroin bukanlah untuk mengisi pundipundi Taliban seperti yang telah diklaim oleh pemerintah Amerika Serikat dan komunitas internasionl. Justru sebaliknya, hasil dari perdagangan ilegal ini adalah sumber pembentukan kekayaan, sebagian besar menuai oleh adanya kepentingan bisnis dan kriminal yang sama-sama kuat di negara-negara Barat. Kepentingan ini ditopang oleh kebijakan luar negeri AS. Pengambilan keputusan di Departemen Luar Negeri, CIA dan Departemen Pertahanan Amerika Serikat berperan penting dalam mendukung perdagangan bernilai miliaran dolar ini, yang ketiga dalam nilai komoditas setelah perdagangan minyak dan senjata. Perdagangan heroin adalah bagian dari agenda perang. Setalah apa yang dicapai dari perang ini adalah mengembalikan negara narco yang patuh dan dipimpin oleh pemimpin boneka yang telah ditunjuk Amerika Serikat. Kepentingan finansial yang kuat di balik perdangangan narkotika didukung oleh militerisasi segitiga obat-obatan utama dunia dan 
rute trans-pengkapalan, termasuk wilayah Golden Crescent dan wilayah Andean Amerika Selatan (Chossudovsky 2005).

\section{Kesimpulan: Intensi Terselubung Amerika Serikat di Golden Crescent}

Berdasarkan pemaparan diatas dapat disimpulkan bahwa hadirnya fenomena globalisasi menimbulkan isu-isu serta permasalahan yang semakin kompleks dan bersifat lintas batas salah satunya kejahatan transnasional. Dalam kasus perdagangan narkotika di Afghanistan, keberadaan posisi geografis Afghanistan dinilai telah sangat menguntungkan perdagangan narkotika, dan begitu juga sebaliknya. Terletak di jalur atau rute perdagangan darat dan perlintasan Eurasia serta berada di Asia Selatan bagian barat laut dekat dengan Asia Tengah dan Barat yang kaya akan energi, membuat Afghanistan menjadi negara strategis. Wilayah teritorial Afghanistan juga termasuk ke dalam kawasan Golden Crescent yang membuat Afghanistan dikenal sebagai pusat produksi dan distribusi opium global. Opium menjadi komoditas utama perdagangan dan industri Afghanistan, dengan hampir 90\% opium dan heroin global berasal dari negeri ini.

Selain karena posisi yang strategis, kondisi politik dalam negeri Afghanistan yang tidak pernah stabil mempengaruhi perkembangan perdagangan narkotika itu sendiri. Berkuasanya para warlords, ditambah dengan pemerintahan dan birokrasi yang lemah, serta korup, pihak-pihak tersebut dinilai telah meraup banyak keuntungan dari perdagangan narkotika. Hasil dari perdagangan komoditas opium ini kembali digunakan untuk membiayai perang dan memperkuat pasukan militer setiap faksi yang turut serta dalam perang sipil di Afghanistan. Hal ini dibuktikan dengan peningkatan kehadiran militer di setiap ladang opium milik para petani, salah satunya adalah kehadiran militer Amerika Serikat yang turut andil dalam kegiatan perdagangan narkotika di Afghanistan. Dalam pandangan Amerika Serikat, narkotika merupakan komoditas terpenting kedua setelah minyak dan perdagangan senjata. Hal ini ditandai sejak invasi Amerika Serikat ke Afghanistan pada bulan Oktober tahun 2001. Kedatangan Amerika Serikat meningkatkan perdagangan opium di wilayah Golden Crescent. Terdapat fakta baru yang menemukan bahwa perdagangan obat-obatan global memiliki urutan yang sama besarnya dengan perdagangan minyak global. Bahkan IMF memperkirakan bahwa sebagian besar pencucian uang global memiliki keterhubungan dan keterkaitan dengan perdagangan opium dan narkotika di wilayah Golden Crescent. 
Perdagangan narkotika merupakan komoditas global ketiga terbesar setelah minyak dan perdagangan senjata. Penulis melihat terdapat kepentingan bisnis dan finansial yang kuat di balik perdagangan narkotika di Afghanistan. Dari sudut pandang penulis, kontrol geopolitik dan militer atas rute narkotika sama strategisnya dengan jaringan pipa minyak dan gas global. 


\section{Daftar Pustaka}

\section{Buku atau Artikel dalam Buku}

Boivin, Remi, 2013. "Drug Trafficking Networks in the World Economy", dalam Carlo Morselli (ed.), Crime and Networks. New York: Routledge.

Sherman, Jill, 2010. Drug Trafficking. Minneapolis: BDO Publishing Company.

May, Channing. 2017. Transnational Crime and the Developing World. Washington, DC: Global Financial Integrity.

McFarlane, John, 2001. Transnational Crime and the Asia Pacific Security. Oxford: Rowman \& Littlefield Publishers.

\section{Artikel Jurnal}

Boister, Neil, 2003. “'Transnational Criminal Law'?”, European Journal of International Law, 14 (5): 953-976.

Farooq, Syeda Ayesha et al., 2017. "Opium trade and the spread of HIV in the Golden Crescent”, Harm Reduction Journal, 14 (1): 1-10.

\section{Publikasi Resmi}

Kantor Narkotika dan Kejahatan PBB, 2000. United Nations Convention against Transnational Organized Crime and The Protocols Thereto. Wina: United Nations Office on Drugs and Crime.

\section{Arikel Daring}

Chossudovsky, Michel, 2005. “The Spoils of War: Afghanistan's Multibillion Dollar Heroin Trade. Washington's Hidden Agenda: Restore the Drug Trade", Global Research: Centre for Research on Globalization, 14 Juni [daring]. Tersedia dalam https://www.globalresearch.ca/the-spoils-of-war-afghanistan-smultibillion-dollar-heroin-trade/91?utm_campaign=magnet\&utm_ 
source $=$ article_page\&utm_medium $=$ related-articles (diakses pada 19 Desember 2019).

Chossudovsky, Michel. 2007. "Heroin is 'Good for Your Health': Occupation Forces support Afghan Narcotics Trade”, Global Research: Centre for Research on Globalization, 23 Agustus [daring]. Tersedia dalam https://www.globalresearch.ca/ heroin-is-good-for-your-health-occupation-forces-support-afghannarcotics-trade/5514 (diakses pada 19 Desember 2019). 